\title{
Coasts in Peril? A Shoreline Health Perspective
}

\author{
J. A. G. Cooper ${ }^{1,2 *}$ and Derek W. T. Jackson ${ }^{1}$
}

${ }^{1}$ School of Geography and Environmental Science, Ulster University, Coleraine, United Kingdom, ${ }^{2}$ Discipline of Geology, School of Agriculture, Earth and Environmental Sciences, University of KwaZulu - Natal, Durban, South Africa

Most assessments of coastal vulnerability are undertaken from the perspective of the risk posed to humans, their property and activities. This anthropocentric view is based on widespread public perception (a) that coastal change is primarily a hazard to property and infrastructure and (b) that sea defenses (whether soft or hard) are required to mitigate and eliminate coastal hazards. From the perspective of coastal ecosystems, such a view is both perverse and damaging. In this paper we present an alternative approach to coastal assessment that centers on the physical integrity of the coast and its associated ecosystems both now and in the near-future. The shoreline health approach represents a new paradigm for coastal management and is intended to provide a much-needed ecosystem perspective. Its premise is to categorize coasts on the degree to which their ability to function morphodynamically has been compromised by human intervention. We present an expert assessment approach involving five categories that range from "Good Health" (with "Health Warning" and "Minor Wounds" sub-divisions), through "Minor Injury," "Major Injury," "On Life Support" to "Deceased." We illustrate the concept using tabulated examples of each category from cliffed, clastic and delta coasts and demonstrate its utility through two applications. This approach has the potential to quantify the degree to which coastal ecosystems have been damaged and to focus attention on the cumulative impact of human activities on coastal ecosystems.

Keywords: coastal morphodynamics, coastal risk, ecosystem - based management, sea - level change, coastal management, South Africa

\section{INTRODUCTION}

This article was submitted to

Geohazards and Georisks,

a section of the journal

Frontiers in Earth Science

Received: 13 February 2019

Accepted: 20 September 2019

Published: 02 October 2019

Citation:

Cooper JAG and Jackson DWT (2019) Coasts in Peril? A Shoreline Health Perspective.

Front. Earth Sci. 7:260

doi: 10.3389/feart.2019.00260

The earth's most diverse and productive ecosystems occur at the coast (Ray, 1988). They deliver a host of ecosystem services (Barbier et al., 2011; Jones et al., 2011) and are intensively inhabited by humans. Coastal human communities are susceptible to a variety of natural hazards (flooding, inundation, erosion, and sedimentation) that are driven by episodic events (storms and tsunami, etc.) and long-term changes in sediment supply, sea level, and climate.

Physical coastal change is consequently viewed from an anthropocentric natural hazard or vulnerability perspective (McGranahan et al., 2007; Meur-Férec et al., 2008; Dawson et al., 2009; Serafim et al., 2019) based on societal concern about risks to infrastructure and property (Bonetti and Woodroffe, 2016; Bonetti et al., 2018). There is a widespread public perception that sea defenses are required to mitigate and eliminate coastal hazards (Cooper and McKenna, 2008; Pilkey and Cooper, 2014), creating a demand for "adaptation" measures that resist coastal change 
(Cooper and Pile, 2014). This view is underpinned by regional and global assessments that portray high risk in areas that lack coastal defenses (Vafeidis et al., 2008; Hinkel et al., 2014, 2015).

Shoreline stabilization impacts on ecosystem functioning and causes loss of habitat (Cooper and Pilkey, 2012). Activities such as beach nourishment and dredging have immediate local impacts, while other, and longer term impacts (e.g., sediment reduction) are less readily appreciated. Poor public understanding of the negative impacts of shoreline stabilization and a widespread demand for protection of human interests is supported by widespread application of coastal vulnerability indices (Thieler and Hammar-Klose, 2000; Abuodha and Woodroffe, 2010; McLaughlin and Cooper, 2010; Nguyen et al., 2016).

To encourage a paradigm shift in society's view of physical coastal change, we present a new approach that assesses human risks to the ecosystem, rather than ecosystem risks to human interests. The approach involves a rapid assessment of the physical status of a coast and of its ability to function. Natural functioning implies a coast's ability to respond to changes from external dynamic forcing within the constraints imposed by its internal characteristics in order to retain the system's integrity (resilience) both now and in the near future.

\section{MEASURES OF PHYSICAL SHORELINE HEALTH}

Ecosystem Health (Costanza et al., 1992) is a complex concept that involves physical, chemical and biological components that interact with each other in the presence of human activity. The metaphor of ecosystem health is also appropriate to the consideration of the status of physical coastal systems. Like organisms, they respond to external and internal stimuli and their ability to do so can be compromised to varying degrees by human actions. We take the view that from a physical viewpoint, any natural coastal system is at the optimum state and cannot be "improved" to achieve "optimum goals" (Barbier et al., 2008).

Physical coastal systems represent a complex interaction of dynamics (wind, waves, and tides), and materials (sediment and rock) within a particular geological framework. The interaction involves internal constraints, external dynamics and feedbacks at various temporal and spatial scales (Cooper et al., 2018), and is encompassed in the concept of morphodynamics (Woodroffe, 2002). Our approach is to determine the extent of human interventions that alter, or have the potential to alter, the natural system. We assess the health of the coastal system according to the degree to which the system's integrity and functioning has been compromised by past and present human activities (and may be impacted in the future by structures or activities that inhibit its response to sea level rise). This approach is in direct contrast to the view (e.g., Lazarus et al., 2016) of coasts as coupled humannatural systems; we view human intervention as compromising coastal functioning.

The universal view of pollution as negative means that the assessment of coastal water and sediment quality is straight forward (e.g., Cooper et al., 1994). Similarly, biotic measures of ecosystem health can readily be conducted by comparison to reference conditions (e.g., Harrison and Whitfield, 2004). The health of the physical coastal ecosystem, however, depends on its ability to adjust and respond to environmental changes now and in the near-future, and this is routinely overlooked in ecosystem assessments. This distortion is likely a result of the dominance of the competing "hazard paradigm" that focusses on human risks from shoreline processes.

Impacts on physical coastal systems arise from human activities both at the coast and distant from it. They involve the following kinds of intervention:

- Alteration of hydrodynamics (e.g., by coastal structures onshore and offshore).

- Alteration of accommodation space/surrounding geological framework (e.g., by construction of harbors, groins, and seawalls).

- Changes in sediment supply (removal/addition) (e.g., by damming rivers, sand extraction, dredging, and beach replenishment).

- Direct impact on existing coastal systems (e.g., by urbanization, land claim, and construction directly on parts of the existing coastal system). The loss can be total or partial.

- Impacts that constrain the coast's future ability to adjust (to sea-level change and future storms) (e.g., roads, buildings, or other impediments to the landward or alongshore migration of landforms).

By assessing the extent to which these impacts are present, it is possible to diagnose the present and near-future state of the coastal morphodynamic system. This can be done through expert assessment when sufficient knowledge is available for any stretch of coast. Below we present a framework for health assessment and apply it in two contrasting settings.

\section{ASSESSING COASTAL HEALTH STATUS}

The coast's ability to function morphodynamically is a measure of its health. This implies an ability to change in response to dynamic forcing (especially storms) and to longer term natural changes in sediment supply and volume. At a time of global sea level rise, the ability of a coast to adjust in the near future is also important (our approximate temporal scale is the next century). We propose a diagnosis of shoreline health using a medical terminology to define a spectrum of categories. These range from a system that is in "Good Health" through to one that is beyond remedial care and is functionally "Deceased." These categories reflect the degree to which human activities modify or constrain the natural operation of coastal processes. The major categories are listed below and a fuller description with examples of each condition is provided in Table $\mathbf{1}$ for cliffed, clastic and delta coasts. With knowledge of the physical processes and background conditions for a given coast this approach can be applied by a suitably experienced geomorphologist.

1. Good Health: no human impediment to shoreline ecosystem functioning. 
TABLE 1 | Shoreline health categories with descriptors for (i) cliffed (soft or hard rock cliffs), (ii) clastic (sand or gravel beaches, barriers, and headand-embayment coasts), and (iii) deltas.

\begin{tabular}{|c|c|c|c|}
\hline Shoreline health category & Rock coast & $\begin{array}{l}\text { Clastic coast (barrier/lagoon, } \\
\text { headland-embayment) }\end{array}$ & Delta coast \\
\hline General descriptors & Descriptor/example & Descriptor/example & Descriptor/example \\
\hline $\begin{array}{l}\text { 1. Good health: There is no } \\
\text { human impediment to } \\
\text { shoreline ecosystem } \\
\text { functioning now or in the } \\
\text { near future }\end{array}$ & $\begin{array}{l}\text { A natural rock coast where erosion } \\
\text { poses no immediate threat to property } \\
\text { or infrastructure and eroded material } \\
\text { can move freely according to wave } \\
\text { action. It may sustain adjacent }\end{array}$ & $\begin{array}{l}\text { A natural beach or barrier system with no } \\
\text { impediment to cross-shore or longshore } \\
\text { sediment movement. No interference in } \\
\text { sediment supply and space available for } \\
\text { landward migration }\end{array}$ & $\begin{array}{l}\text { A delta coast with no existing major } \\
\text { impoundments and no impediments to } \\
\text { sediment dispersal at the coast (e.g., } \\
\text { Rovuma and Mozambique) }\end{array}$ \\
\hline
\end{tabular}

1a. Health warning: Actual or planned human structures or planned activities impede the coast's ability to evolve in the near future. The future impact on the system will depend on human response to perceived threats

1b. Surface wounds/scar tissue. Actual human intervention is evident but is not creating problems or past human activity has caused damage. These activities have since stopped and the system is continuing to operate

2. Minor Injury (coast can recover). Human intervention modifies the morphology or rates of sediment supply such that the system continues to operate but differently from its natura condition

3. Major Injury (potentially fatal)

4. On life support (system is maintained only by regular human intervention)

5. Deceased (system has been eliminatedcovered/eroded/degraded) sedimentary deposits on the rocky coast.

Infrastructure in proximity to cliff edge poses threat to future cliff mobility
Problems are imminent. For example, a developed area landward of active coastal system with no plan for relocation in the event of sea-level rise (e.g., Balneario Camboriu, Brazil; Gold Coast, Australia)

Small scale sediment removal Past damage from human activities but now stopped and system is recovered/recovering (e.g., scars from former dune mining, Sefton Coast, England; erosion of man-made "dune" on Outer Banks, North Carolina)

Mediterranean (Knidos and Turkey); Decayed sea defenses at Happisburgh, England)

Small scale or discontinuous sea defenses. These cause a local reduction in rates of cliff retreat and associated sediment supply (e.g., Streckelsberg, Germany)

Extensive sea defenses severely reduce or locally halt cliff retreat, impacting cliff processes and sediment supply (e.g., Antrim Coast Road, Northern Ireland)
Defenses to halt cliff recession eliminate sediment supply to adjacent areas. These are maintained by artificial beach replenishment (e.g., Barton-on-Sea and High cliffe, England)

Cliff has been stabilized, covered by concrete or isolated from wave processes by structures. It no longer operates as a sedimentary system (e.g., Withernsea, Yorkshire)
A single structure causes changes in the sedimentary system. For example, a groin or jetty interrupts sediment supply, causing updrift accumulation, and downdrift erosion- (e.g., Ocean City Maryland). The system continues to operate but with a different morphology and rates of change.

Often evolving from minor injury category, whereby additional measures are put in place in respinse to changes associated with initial intervention. This usually involves numerous structures (jetties, groins, and seawalls) and/or beach nourishment as the impacts extend along the shoreline (e.g., Multiple breakwaters, Donnalucata, Sicily; multiple groins, Sussex coast, England).

$A$ beach which is maintained only by ongoing artificial replenishment (e.g., Benidorm, Spain, Gold Coast, Australia) or a tidal inlet system maintained by dredging of channel and tidal deltas (e.g., most inlets on East coast of United States)

The sedimentary system has been destroyed. For example, sand has been mined to the extent that a beach has disappeared (e.g., Hallsands, England), or coastal structures obliterate the former system (e.g., Portcawl, Wales), or a seawall has prevented beach migration, causing beach loss (e.g., Nantasket Beach, Boston, Pudicherry, India)
Planned near-future activities (e.g., dam construction) poses a future threat (e.g., Rufiji and Tanzania)
Farming on delta plain, urban development, salt production, but no substantial impact on delta sedimentary system (e.g., Menderes, Turkey). Former human interventions are abandoned and system begins to recover. e.g., Dredged channels are abandoned and begin to silt-up

Sediment supply is somewhat reduced, some channels are dredged, and some inlets have jetties but much of the delta remains in a natural condition (e.g., Zambezi Delta, Mozambique)

Sediment supply is severely reduced, urbanization is widespread on delta surface, delta shoreline has been heavily modified (e.g., shrimp farms replace mangroves, dykes, and sea defenses abound (e.g., Red River Delta, Vietnam)

The delta sedimentary system has been severely disrupted. Some parts of the system are maintained by human interventions (e.g., Mississippi, United States)

The delta sediment supply is severely reduced, sudsidence continues, the delta surface is heavily developed and flooding and erosion are serious issues (e.g., Chao Phraya, Thailand) or the delta is dessicated and being reworked (e.g., Colorado Delta, Mexico) 
(Sub-division: With Health Warning): position of human infrastructure may cause concern in the near future - requires planning for future status.

Sub division (Surface Wounds/Scar Tissue): the surface has been modified - e.g., by agriculture, vegetation alteration, recreational space, and/or there are remains of past damage.

1. Minor Injury: despite human interventions, the system continues to operate but in a diminished way (e.g., by small scale, discontinuous coastal defenses).

2. Major Injury: alteration of sediment supply (e.g., by dams, mining, dumping), or dynamics (by groins, offshore structures, beach being squeezed against seawall, sediment supply fatally compromised, and cliff stabilized). Such systems are capable of resuscitation - e.g., Durham Coast of England.

3. On Life Support: system maintained only by continued human intervention, e.g., beach nourishment.

4. Deceased: The natural coastal system has been eliminated (covered, eroded, and degraded).

\section{SPATIAL APPLICATION}

To demonstrate the approach, we consider two contrasting shorelines: North of Durban, South Africa (Figure 1), and NW Northern Ireland (Figure 2).

The jetties at the mouth of Durban Harbor (Figure 1) interrupt the longshore sediment transport and alter wave conditions such that the Durban beachfront is sediment-starved. The presence of high-rise beachfront development and associated infrastructure immediately landward of (and in some cases on top of) the beach, impedes future migration of the shoreline. The contemporary beach is sustained only by beach replenishment and groins to retain the placed sand. Several recent erosion incidents have highlighted the area's total reliance on artificial sand placement to sustain the ecosystem. It is thus firmly in the "On Life Support" category.

Northward, at the mouth of the Mgeni River the coastline emerges from a zeta-bay configuration to become a linear sandy coast with occasional outcrops of bedrock. The Mgeni River has been heavily dammed. The most recent dam (completed in 1988) is $32 \mathrm{~km}$ upstream of the coast. It has reduced the sediment supply, particularly during fluvial floods (Cooper et al., 1990), and beaches are anticipated to become narrower as a result (Garland and Moleko, 2000). For this reason, a $2.5 \mathrm{~km}$ stretch of coast downdrift of the Mgeni has been categorized in the "Minor Injury" category. This was chosen over "Major Injury" because the coastal system will continue to operate, but at a different rate. The extent to which the loss of the Mgeni system affects the overall northward longshore transport (Schoonees, 2000) is not known, but the longshore drift to the north is not wholly reliant on the Mgeni River; beyond the lee of the Durban jetties, longshore drift is augmented by sediment that bypasses the harbor entrance. Northwards, the coast is backed by a healthy forested dune, with a golf course and airstrip to landward. These do not impinge on the dune and do not pose an imminent threat to coastal migration. Consequently, this stretch of coast is classified in "Good Health." Northward, the coastline is developed to varying degrees of intensity from large single-family units to multi-unit high-rises at Umhlanga Rocks. All of this development has impinged on or obliterated coastal dunes, and they pose an immediate impediment to modern and near-future shoreline change as evidenced by coastal erosion and property damage during a succession of storms in 2007-2008 (Smith et al., 2010). This is assigned to category "1a: Health Warning," because the coast's future state depends upon human adaptation actions. A retreat from the coast will enable it to recover its health. Construction of hard defenses will place it in the "Major Injury" category and the implementation of beach nourishment would place it on "Life Support."

North of Umhlanga Rocks, the lagoon, barrier beach and dunes are not affected by human activity in such a way as to impede natural processes (="Good Health"). An increase in discharge from a water treatment works has increased the frequency of barrier breaching on the Mhlanga Lagoon (Cooper, 2014). This constitutes a change in frequency rather than a restriction on natural processes and so is discounted in this classification. Northward the coast reverts to a "1a Health Warning" status in the area of Umdloti where a combination of high and low-rise developments and road infrastructure impede future migration of the shoreline.

In the Northern Ireland case study (Figure 2) are examples of some additional categories. In the west, a former salt marsh has been subject to land claim and is fronted by a sea defense that isolates it from the remnant tidal flats. To this extent, the shoreline is regarded as "Deceased." Much of the remaining estuarine shoreline is eroding in response to wind-generated estuarine waves, and yielding sediment to the tidal flats. This stretch is in "Good Health." This area provides a useful example of the direct contradiction between shoreline health and the prevailing "risk-orientated" views. Landowners regularly appeal for help to protect property on this eroding shoreline and it's soft, low-lying nature, with the high and consistent rates of shoreline recession would typically identify it as an area of high risk (Cooper and McLaughlin, 1998). At a local scale, some areas have been subject to periodic small-scale attempts to hold the shoreline, but these have been ineffective and do not interfere with the coastal system. They are, in any case too small to map at this scale and are in fact prohibited by existing nature conservation designations. Mapping at a larger scale would likely place them in the "Surface Wounds" category. Similarly, a small jetty near the apex of Magilligan Point appears to cause only local perturbations, rather than a major impact on the coastal system.

The ocean shoreline as far as Portrush is under a variety of conservation designations and is not affected in any major way by human activities or infrastructure. At Portrush, however, a seawall at the rear of West Strand has isolated the beach from adjacent eroding dunes and has led to a lowering and narrowing of the intertidal beach (Carter, 1991). This is regarded as a "Major Injury" that may prove fatal to the coastal system. On the adjacent rocky coast "Surface Wounds" are evident in the form of small concrete structures built to facilitate boat launching 


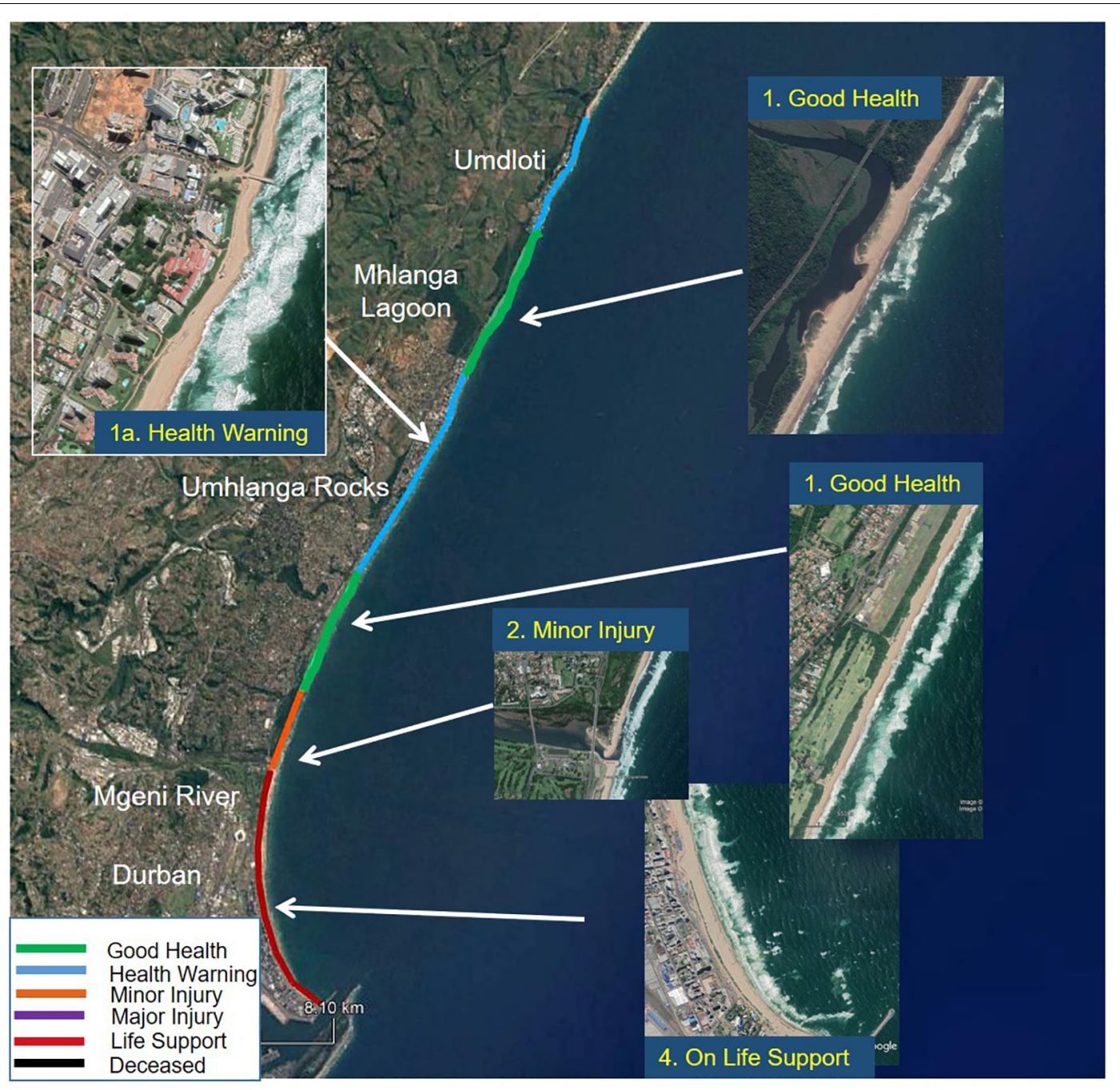

FIGURE 1 | Shoreline Health assessment of a section of the KwaZulu - Natal Coast of South Africa. For description see text. Main image and insets from Google Earth, Map data: SIO, NOAA, U.S. Navy, GEBCO, and AFRIGIS. Data (Insets) 2019 Digitalglobe.

and which may interfere with the movement of material on the shore platform.

Beyond this is an area where the sand dunes are occupied by a golf course. Limited armoring of the base of the dunes has been carried out along a $50 \mathrm{~m}$ frontage. Likely shoreline recession under continued sea-level rise, is likely to lead for calls for more armoring, and consequently, this stretch of coast has a Health Warning because of likely future management options that may cause a deterioration in its status. To the east, a stretch of undeveloped rocky coast is under conservation designations and ownership of conservation charities. It is in "Good Health." An exception is the small formerly sandy beach at Portballintrae. As a result of successive human interventions this has been almost entirely eroded, the backing cliffs have been stabilized and armored and the wide sandy beach replaced by a narrow gravel beach on an eroded bedrock surface (Jackson, 2012), placing this coast in the "Deceased" category.

\section{CAN COASTS RECOVER?}

For shorelines that have not been fatally damaged, it may be possible to prescribe a remedy such that the shoreline recovers. Like applying a stent in a human heart patient, the health of a shoreline can be greatly improved by removal or repair of damaged parts. A few examples serve to illustrate the principle.

On the west coast of the United States dam construction during the 20th century reduced fluvial sediment supply to the coast, causing erosion in several locations. Recognition of this fact and the desire to reinstate the hydrological regime, led to the deliberate removal of several dams. The Elwha delta in Puget Sound, Washington was studied in detail after removal of a dam in 2011 (Gelfenbaum et al., 2015). An equivalent of 100 years sediment supply was delivered to the coast within 2 years of dam removal. The delta showed significant progradation and development of subtidal and intertidal landforms. Sediment was 


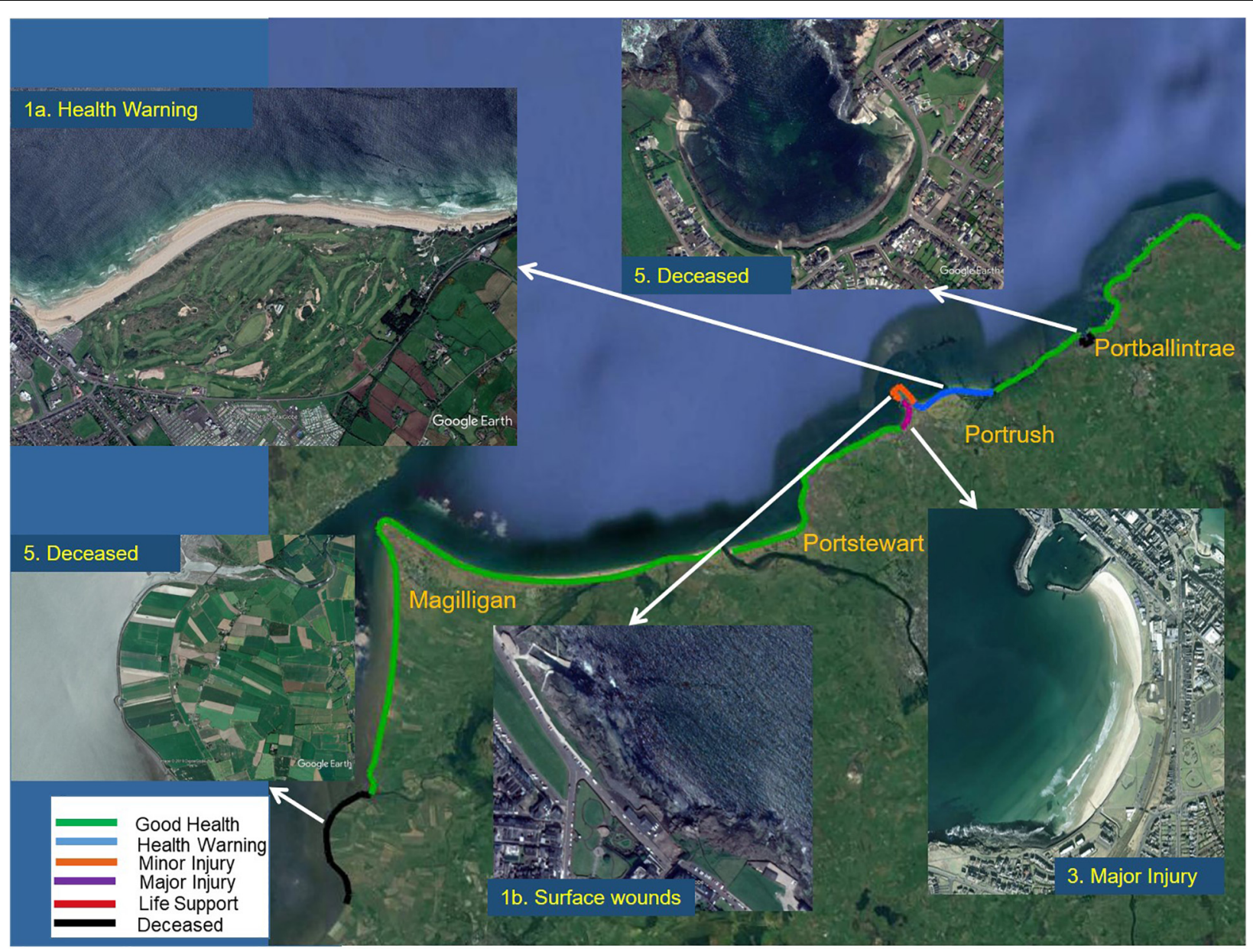

FIGURE 2 | Shoreline Health assessment of a section of the north coast of Northern Ireland. For description see text. Main image and insets from Google Earth. Data (Main Image): SIO, NOAA, U.S. Navy, and GEBCO. Data (Insets) 2019 Digitalglobe.

also delivered from the delta to adjacent stretches of coast, restoring the coastal system's morphodynamic function.

On a $12 \mathrm{~km}$ stretch of the County Durham Coast in northeast England, 40 million tones of colliery waste was dumped directly on adjacent beaches during the 20th century up to 1993 when mining ceased (Johnson and Frid, 1995). Wave action reworked the leading edge of some of the waste deposits, creating a functioning beach system, albeit composed of large proportions of brick, concrete and ironwork, as well as the coal tailings. However, the beaches were severely degraded: sulfur was being precipitated and the beach interstitial waters were highly acidic (Lawrence et al., 2004). In an initiative to clean up the coast (Durham Heritage Coast) derelict structures were removed, and 1.3 million tones of colliery spoil was removed from beaches. The coast has now been rehabilitated and a natural sedimentary system is being reinstated after a century of damaging intervention.

The practice of "managed realignment" (Esteves, 2014), whereby attempts are made to restore formerly degraded salt marshes by breaching sea defenses and allowing reflooding of agricultural lands is primarily a habitat-creation scheme. Although few such schemes have been adequately monitored, the perception is that such interventions can resuscitate a dying ecosystem, although some assessments point to differences in vegetation structure of reclaimed marshes compared to natural equivalents (Mossman et al., 2012).

These examples illustrate that, as long as the damage is not too great (up to and including the "Major Injury" category), and there is a willingness to do so, shorelines can be nursed back to health through remedial action to remove the damaging interventions. In areas that have suffered high levels of degradation, however, recovery may not be possible. In many instances, it is acknowledged that only partial restoration is possible (Simenstad et al., 2006), but the coastal ecosystem continues to exist and operate in a diminished way. On some such severely impacted coasts, attempts have also been made to create artificial habitats, e.g., coastal dunes. These usually require continued intervention and maintenance. Such systems are not examples of recovery of deceased coastal systems but are artificial substitutes that replace the former system. They are common 
on nourished beach systems (Nordstrom and Mauriello, 2001) and are symptomatic of coasts in the "Life Support" category. On other "Deceased" coastal systems artificial coastal habitats (Nordstrom and Jackson, 2013), are not examples of restoring the health of a system, rather they are substitutes.

\section{DISCUSSION}

Preoccupation with the potential impact of coastal hazards on property and infrastructure has distorted approaches to assessing and managing physical coastal systems. This "anthropocentric view" has had a damaging effect by encouraging initiatives that damage the ecosystem. As a prelude to changing this view, an easily understood and easily applied measure of shoreline health is needed that assesses the degree to which physical coastal systems can operate. Our 5-category health assessment represents such an approach. This approach may require further codification, and particularly of boundary definitions between the various classes, but we present the approach as a viable and necessary alternative to coastal vulnerability indices, set firmly within the ecosystem-based management paradigm. Human activities, property and infrastructure are seen as potential impediments to the continued functioning of natural coastal systems, rather than as assets to be protected from natural patterns of coastal change.

Human activities have inflicted damage on coastal systems for centuries or longer and, in many cases, it is difficult to identify these impacts. Human-induced changes in sediment supply, for example, have been widely reported from antiquity to the modern period (e.g., Hein et al., 2014). Some of these impacts continue

\section{REFERENCES}

Abuodha, P. A., and Woodroffe, C. D. (2010). Assessing vulnerability to sealevel rise using a coastal sensitivity index: a case study from southeast Australia. J. Coast. Conserv. 14, 189-205. doi: 10.1007/s11852-0100097-0

Barbier, E. B., Hacker, S. D., Kennedy, C., Koch, E. W., Stier, A. C., and Silliman, B. R. (2011). The value of estuarine and coastal ecosystem services. Ecol. Monogr. 81, 169-193.

Barbier, E. B., Koch, E. W., Silliman, B. R., Hacker, S. D., Wolanski, E., Primavera, J., et al. (2008). Coastal ecosystem-based management with nonlinear ecological functions and values. Science 319, 321-323. doi: 10.1126/science.11 50349

Bonetti, J., de Moraes Rudorff, F., Campos, A. V., and Serafim, M. B. (2018). Geoindicator-based assessment of Santa Catarina (Brazil) sandy beaches susceptibility to erosion. Ocean Coast. Manag. 156, 198-208. doi: 10.1016/j. ocecoaman.2017.08.009

Bonetti, J., and Woodroffe, C. (2016). "Spatial analysis for coastal vulnerability assessment," in Geoinformatics for Marine and Coastal Management, eds D. Bartlett, and L. Celliers, (Boca Raton, FL: CRC Press), 367-395.

Carter, R. W. G. (1991). Near-future sea level impacts on coastal dune landscapes. Landsc. Ecol. 6, 29-39. doi: 10.1007/BF00157742

Costanza, R., Norton, B. G., and Haskell, B. D. (1992). Ecosystem Health: New Goals for Environmental Management. Washington: Island Press.

Cooper, J. A. G. (2014). “Coastal Lakes," in Ugu Lwethu - Our Coast. A Profile of Coastal KwaZulu-Natal, eds B. J. Goble, R. P. van der Elst, and L. K. Oellermann, (Cedara: KwaZulu-Natal Department of Agriculture and Environmental Affairs and the Oceanographic Research Institute), 37-39. to the present, while others involved periods of activity that have long ceased (e.g., mining, or past agricultural practices), but which continue to exert an influence on contemporary coastal systems (Oyedotun, 2016). The baseline against which "natural" conditions are assessed will have to be determined in such instances. However, for most of the world's coast, a straightforward assessment of the degree to which human activities compromise physical coastal functioning now and in the near future is quite feasible.

\section{AUTHOR CONTRIBUTIONS}

JC wrote the manuscript. DJ contributed in development of the concept, discussion of the content, and review of the draft manuscript.

\section{FUNDING}

This work was undertaken in the course of the MarPAMM (Marine Protected Area Management and Monitoring) project. The project is supported by the European Union's INTERREG VA Programme, managed by the Special EU Programmes Body (SEUPB). Match funding was provided by the Department of Agriculture, Environment and Rural Affairs in Northern Ireland and the Department of Housing, Planning and Local Government in Ireland. The views and opinions expressed in this paper do not necessarily reflect those of the European Commission or the Special EU Programmes Body (SEUPB).

Cooper, J. A. G., Green, A. N., and Loureiro, C. (2018). Geological constraints on mesoscale coastal barrier behaviour. Glob. Planet. Change 168, 15-34. doi: 10.1016/j.gloplacha.2018.06.006

Cooper, J. A. G., Mason, T. R., Reddering, J. S. V., and Illenberger, W. K. (1990). Geomorphological effects of catastrophic flooding on a small subtropical estuary. Earth Surf. Process. Landf. 15, 25-41. doi: 10.1002/esp.3290150104

Cooper, J. A. G., and McKenna, J. (2008). Working with natural processes: the challenge for coastal protection strategies. Geogr. J. 174, 315-331. doi: 10.1111/ j.1475-4959.2008.00302.x

Cooper, J. A. G., and McLaughlin, S. (1998). Contemporary multidisciplinary approaches to coastal classification and environmental risk analysis. J. Coast. Res. 14, 512-524.

Cooper, J. A. G., and Pile, J. (2014). The adaptation-resistance spectrum: a classification of contemporary adaptation approaches to climate-related coastal change. Ocean Coast. Manag. 94, 90-98. doi: 10.1016/j.ocecoaman.2013.09.006

Cooper, J. A. G., and Pilkey, O. H. (eds) (2012). Pitfalls of Shoreline Stabilization: Selected Case Studies. Dordrecht: Springer.

Cooper, J. A. G., Ramm, A. E. L., and Harrison, T. D. (1994). The estuarine health index: a new approach to scientific information transfer. Ocean Shoreline Manag. 25, 103-141. doi: 10.1016/0964-5691(94)90043-4

Dawson, R. J., Dickson, M. E., Nicholls, R. J., Hall, J. W., Walkden, M. J., Stansby, P. K., et al. (2009). Integrated analysis of risks of coastal flooding and cliff erosion under scenarios of long term change. Clim. Change 95, 249-288. doi: 10.1007/s10584-008-9532-8

Durham Heritage Coast, Available at: http://www.turning-the-tide.org.uk/ (accessed September 25, 2019).

Esteves, L. S. (2014). Managed Realignment: A Viable Long-Term Coastal Management Strategy? Dordrecht: Springer. 
Garland, G., and Moleko, L. (2000). Geomorphological impacts of Inanda Dam on the Mgeni estuary, north of Durban, South Africa. Bull. Eng. Geol. Environ. 59, 119-126. doi: 10.1007/s100640000057

Gelfenbaum, G., Stevens, A. W., Miller, I., Warrick, J. A., Ogston, A. S., and Eidam, E. (2015). Large-scale dam removal on the Elwha River, Washington, USA: coastal geomorphic change. Geomorphology 246, 649-668. doi: 10.1371/journal. pone. 0187742

Harrison, T. D., and Whitfield, A. K. (2004). A multi-metric fish index to assess the environmental condition of estuaries. J. Fish Biol. 65, 683-710. doi: 10.1016/j. marpolbul.2008.07.020

Hein, C. J., FitzGerald, D. M., Buynevich, I. V., Van Heteren, S., and Kelley, J. T. (2014). Evolution of paraglacial coasts in response to changes in fluvial sediment supply. Geol. Soc. Lond. Spec. Publ. 388:247. doi: 10.1144/sp388.15

Hinkel, J., Jaeger, C., Nicholls, R. J., Lowe, J., Renn, O., and Peijun, S. (2015). Sealevel rise scenarios and coastal risk management. Nat. Clim. Change 5, 188-190. doi: $10.1038 /$ nclimate 2505

Hinkel, J., Lincke, D., Vafeidis, A. T., Perrette, M., Nicholls, R. J., Tol, R. S., et al. (2014). Coastal flood damage and adaptation costs under 21st century sea-level rise. Proc. Natl. Acad. Sci. U.S.A. 111, 3292-3297. doi: 10.1073/pnas. 1222469111

Jackson, D. W. (2012). "Portballintrae Bay, Northern Ireland: 116 years of misplaced management," in Pitfalls of Shoreline Stabilization, eds J. Cooper, and O. Pilkey, (Dordrecht: Springer), 93-104. doi: 10.1007/978-94-007-4123-2_6

Johnson, L. J., and Frid, C. L. J. (1995). The recovery of benthic communities along the County Durham coast after cessation of colliery spoil dumping. Mar. Pollut. Bull. 30, 215-220. doi: 10.1016/0025-326x(94)00145-y

Jones, L., Angus, S., Cooper, A., Doody, P., Everard, M., Garbutt, A., et al. (2011). Coastal Margin Habitats. in UK National Ecosystem Assessment. Understanding Nature's Value to Society. Technical Report. Cambridge: UNEP-WCMC.

Lawrence, D. J., Vye, C. L., and Young, B. (2004). Durham Geodiversity Audit. Available at: https://www.durham.gov.uk/media/3683/CountyDurham-Geodiversity-Audit/pdf/CountyDurhamGeodiversityAudit.pdf? $\mathrm{m}=635901951858470000$ (accessed September 25, 2019).

Lazarus, E. D., Ellis, M. A., Murray, A. B., and Hall, D. M. (2016). An evolving research agenda for human-coastal systems. Geomorphology 256, 81-90. doi: 10.1016/j.geomorph.2015.07.043

McGranahan, G., Balk, D., and Anderson, B. (2007). The rising tide: assessing the risks of climate change and human settlements in low elevation coastal zones. Environ. Urban. 19, 17-37. doi: 10.1177/0956247807076960

McLaughlin, S., and Cooper, J. A. G. (2010). A multi-scale coastal vulnerability index: a tool for coastal managers? Environ. Hazards 9, 233-248. doi: 10.3763/ ehaz.2010.0052

Meur-Férec, C., Deboudt, P., and Morel, V. (2008). Coastal risks in France: an integrated method for evaluating vulnerability. J. Coast. Res. 24, 178-189. doi: 10.2112/05-0609.1

Mossman, H. L., Davy, A. J., and Grant, A. (2012). Does managed coastal realignment create saltmarshes with 'equivalent biological characteristics' to natural reference sites? J. Appl. Ecol. 49, 1446-1456. doi: 10.1111/j.1365-2664. 2012.02198.x

Nguyen, T. T., Bonetti, J., Rogers, K., and Woodroffe, C. D. (2016). Indicatorbased assessment of climate-change impacts on coasts: a review of concepts, methodological approaches and vulnerability indices. Ocean Coast. Manag. 123, 18-43. doi: 10.1016/j.ocecoaman.2015.11.022

Nordstrom, K. F., and Jackson, N. L. (2013). "Foredune restoration in urban settings," in Restoration of Coastal Dunes. Springer Series on Environmental Management, eds M. Martínez, J. Gallego-Fernández, and P. Hesp, (Berlin: Springer), 17-31. doi: 10.1007/978-3-642-33445-0_2

Nordstrom, K. F., and Mauriello, M. N. (2001). Restoring and maintaining naturally-functioning landforms and biota on intensively developed barrier islands under a no-retreat alternative. Shore Beach 69, 19-28.

Oyedotun, T. D. T. (2016). Historical mining signatures: geochemical and mineralogical evaluation of sediments in three coastal-estuarine systems. J. Coast. Zone Manag. 19:432.

Pilkey, O. H., and Cooper, J. A. G. (2014). The Last Beach. Durham, NC: Duke University Press.

Ray, G. C. (1988). "Ecological diversity in coastal zones and oceans," in Biodiversity, ed. E. O. Wilson, (Washington, DC: National Academy of Sciences/ Smithsonian Institution), 36-50.

Schoonees, J. S. (2000). Annual variation in the net longshore sediment transport rate. Coast. Eng. 40, 141-160. doi: 10.1016/S0378-3839(00)00009-0

Simenstad, C., Reed, D., and Ford, M. (2006). When is restoration not?: Incorporating landscape-scale processes to restore self-sustaining ecosystems in coastal wetland restoration. Ecol. Eng. 26, 27-39. doi: 10.1016/j.ecoleng.2005. 09.007

Serafim, M. B., Siegle, E., Corsi, A. C., and Bonetti, J. (2019). Coastal vulnerability to wave impacts using a multi-criteria index: Santa Catarina (Brazil). J. Environ. Manage. 230, 21-32. doi: 10.1016/j.jenvman.2018.09.052

Smith, A. M., Mather, A. A., Bundy, S. C., Cooper, J. A. G., Guastella, L. A., Ramsay, P. J., et al. (2010). Contrasting styles of swell-driven coastal erosion: examples from KwaZulu-Natal. South Africa. Geol. Mag. 147, 940-953. doi: $10.1017 / \mathrm{s} 0016756810000361$

Thieler, E. R., and Hammar-Klose, E. S. (2000). National Assessment of Coastal Vulnerability to Sea-Level Rise; Preliminary Results for the US Gulf of Mexico Coast. USGS Open File Report No. 2000-2179. Reston, VA: United States Geological Survey.

Vafeidis, A. T., Nicholls, R. J., McFadden, L., Tol, R. S., Hinkel, J., Spencer, T., et al. (2008). A new global coastal database for impact and vulnerability analysis to sea-level rise. J. Coast. Res. 24, 917-924. doi: 10.2112/060725.1

Woodroffe, C. D. (2002). Coasts: Form, Process and Evolution. Cambridge: Cambridge University Press.

Conflict of Interest: The authors declare that the research was conducted in the absence of any commercial or financial relationships that could be construed as a potential conflict of interest.

Copyright (c) 2019 Cooper and Jackson. This is an open-access article distributed under the terms of the Creative Commons Attribution License (CC BY). The use, distribution or reproduction in other forums is permitted, provided the original author(s) and the copyright owner(s) are credited and that the original publication in this journal is cited, in accordance with accepted academic practice. No use, distribution or reproduction is permitted which does not comply with these terms. 